\title{
MERAMAL KRISIS KEUANGAN DI INDONESIA
}

\author{
Oleh :
}

Teguh Sihono

tesih@uny.ac.id

\section{Abstract}

The policy makers in Indonesia is more Ad-hoc and myopic (the radar far) to make policy. With various models and methods can be made a prediction or forecast about the financial and banking crisis, and even can diagnose the health of can economy. The crisis that can accur in various parts of the world causing expertsto try to find the cause, a common pattern (stylized facts) that is expected to developed a method to detect the financial crisis, it can even be used to see in the future economy performance. Crisis in Indonesia that occurred in 1971 - 1975 as the sample to predict a crisis of Indonesia in 1997 whose results were in general quite.

There are several models developed to predict the financial crisis imn Indonesia include: parametric models/econometric models and non parametric, such as signals, the model logit/probit, hybrid model that includes macro and micro prudential and artificial neural network model. Each using a similar indicator, only the number of indicators (its nodes) are indeed different.

From the various models and methods developed, has the performance and results of analysis or early indicators are almost the same/similar and significant at 5\%, alpha level. It's just an early indicator of the difference and the probability that a crisis will occur when using a forecasting and prediction in outside sample. The performance of each model is adequate in terms of occurancy in predicting the probability of financial crisis in Indonesia. Early indicators are an important contribution in predicting the probability of financial crisis in Indonesia are: real exchange rate, fiscal deficit, the credit ratio to Gross Domestic Product (GDP), world oil prices, growth in export and import, government consumption, domestic imterest rate spread is the interest rate "The Fed" (The Federal Reserve/The Central Bank of The USA)

\section{PENDAhuluan}

Kisis keuangan pada pinjaman subprime mortgage pertengahan tahun 2007 di Amerika Serikat diperhitungkan akan berakibat ke seluruh penjuru dunia. Pada awal 
oktober tąun 2008, krisis tersebut meluas dan menjadi pemicu krisis keuangan yang lebih luasmencakup pasar modal dan perbankan. Harga saham di New Stock Exchange terus berjatuhan, pada tanggal 6 Oktober 2008 indeks harga saham Dow Jones jatuh dibawah 10.000 yang berefek domino keseluruh antero dunia. Demikian pula harga saham gabungan (IHSG) di BEl (Bursa Efek Indonesia) jatuh beruntun sejak tanggal 6 Oktober 2008, sehingga tanggal 8 Oktober 2008 pukul 11.08, perdagangan dihentikan sementara (bahkan ditutup tiga hari) karena sudah jatuh sebesar 10,38\%, sejak dibuka. Kyrs rupiah juga jatuh bahkan menyentuh di atas $\mathrm{Rp}$ 10,000,00 per 1 dollar Amerika Serikat.

Fenomena ini menyadarkan kita semua bahwa sebuah krisis ekonomi atau keuangan sering dikaitkan dengan buruknya tata kelola perekonomian dan sistem ekonomi yằng kurang ramah terhadap pasar. Fakta menunjukkan bahwa sistem ekonomi yang berbasis pasar (market based economy) juga tidak menjamin suatu negara kebal terhadap kemungkinan krisis keuangan atau berbagai krisis sejenis di sektor keuangan, seperti krisis di pasar modal dan perbankan.

Krisis keuangan yang sering terjadi di berbagai belahan dunia menyebabkan para ahli mencoba untuk mengetahui penyebabnya, pola umumnya (stylized facs) yang diharapkan dapat mengembangkan motode untuk mendeteksi krisis keuangan. Radelet dan Sachs (1998) membaginya ke dalam 5 tipe penyebab krisis keuangan yaitu kebijakan ekonomi yang tidak konsisten, kepanikan di pasar uang, pecahnya gelembung finansial, ketiadaan aturan baku dan moral hazard. Krisis keuangan dapat saja terjadi tidak hanya bersumber dari satu penyebab tunggal dari faktor-faktor tersebut, tetapi dari berbagai faktor yang saling bersinergi. Secara teoritis, analisis krisis keuangan dapat dibagi menjadi empat generasi, generasi pertama, ke dua, dan ketiga krisis keuangan, sedar.gkan generasi ke empat teori diluar sistem generasi.

Berbagai model empirik telah dikembangkan guna membantu mendeteksi krisis keuangan secara dini. Model yang paling konvensioanal yaitu model parametrik atau ekonometrik dengan analisis 
probit atau logit. model signal yang juga sering disebut dengan model non parametrik. model yang lebih kompleks seperti model jaringan saraf buatan, dan model hibrida, model yang sangat sederhana yang disebut macroprudential dan microprudential untuk memantau risiko akan terjadinya krisis keuangan.

Hasil pengembangan model krisis keuangan dengan pendekatan signal, ternyata cukup memadai. Model ini dapat meprediksi krisis keuangan tahun 1997 dan krisis mini pada Agustus 2995 lalu. Kinerja model signal baik untuk sampel maupun di luar sampel cukup memuaskan dengan berbagai alat evaluasi. Sebenarnya model logit cukup memadai untuk meramalkan krisis keuangan 1997, walau tidak sebaik model signal/non parametrik. Model jaringan saraf buatan memberikan hasil yang juga sangat baik untuk krisis kedua diluar sampel. Hal ini menujukkan bahwa krisis keuangan sebenarnya dapat diramalkan bila indikatorindikator ekonomi tertentu yang dipakai sebagai indikator dini menunjukkan perilaku yang abnormal. Yaitu ketika kondisi indikator melampaui rata-rata plus standar deviasinya selama kurun waktu pengamatan. Dari model yang dikembangkan dapat diketahui probabilitas akan terjadinya krisis keuangan dengan masa pra-krisis (window horizon) tertentu. Jikalau masa pra-krisis sudah dapat ditentukan maka sebuah model akan dapat meramalkan terjadinya krisis daam 24 bulan atau 12 bulan mendatang (bila probabilitas sudah mencapai ambang tertentu).

Model sistem peringatan dini krisis keuanga dapat pula dipergunakan untuk mendiagnosis kesehatan perekonomian di masa tenang. Dengan demikian jika kinerja ekonomi memburuk dan akan berakibat pada krisis keuangan, maka kinerja ekonomi dapat diperbaiki dan terhindar dari krisis keuangan.

Indonesia pernah mengalami krisis yang paling akut, diantara negara-negara Asia pada tahun 1997. Sampai saat ini pemerintah belum memiliki sistem deteksi dini yang memadai kecuali di Bank Indonesia. Institusi sebagai penjaga gawang dalam pencegahan krisis keuangan belum tertata dengan baik. Pada saat krisis dan menjelang krisis, pengambilan keputusan harus dilakukan dengan cepat dan terukur, 
agar krisis tidak berlanjut dan lebih dalam. Akan tetapi jika tidak ada prosedur dan mekanisme yang jelas dalam menangani pada masa menjelang dan saat krisis, maka para policy maker tidak ada yang berani mengambil keputusan yang cepat dan terukur, khawatir akan terseret ke masalah yuridis. Oleh sebab itu seyogianya ada sebuah lembaga khusus yang menangani dan bukan hanya sebuah forum seperti FSSK (Forum Stabilitas Sektor Keuangan)

\section{KRISIS DAN SISTEM PERINGATAN DINI}

Pada tahun 2008 dana talangan sebesar US\$700 miliar yang dikeluarkan pemerintah Amerika Serikat, dan tax bates US\$ 800 per rumah yang jumlahnya mencapai US $\$ 150$ miliar yang ditingkatkan pada tahun 2009 menjadi US\$787 miliar (Teguh Sihono. 2009). Tidak mampu menyelamatkan rontoknya harga-harga saham.Harga saham gabungan (IHSG) di Bursa Efek Indonesia jatuh beruntun dan pada tanggal 8 Oktober 2008 pukul 11.08 perdagangan dihentikan sementara, karena jatuh
$10,38 \%$. Suatu krisis ekonomi atau keuangan sering dikaitkan dengan buruknya tata kelola perekonomian dan sistem ekonomi yang kurang ramah terhadap pasar. Namun fakta,menunjukkan bahwa sistem ekonomi yang berbasis pasar juga tidak menjamin akan kebal terhadap krisis ekonomi, keuangan, pasar modal dan perbankan.

Sistem peringatan dini merupakan salah satu cara yang dapat menjaga agar sistem keuangan dapat berjalan sesuai dengan aturannya, dan bila berpotensi krisis akan dapat terdeteksi lebih awal. Secara umum para ekonom sepakat bahwa sistem peringatan dini secanggih apapun metodologi yang digunakan tampak sulit memperkirakan kapan terjadinya krisis keuangan secara tepat. Namun dengan melihat berbagai model yang dikembangkan oleh para ahli, terdapat fenomena umum (stylized facts) yang muncul terhadap berbagai indikator dini yang dapat dilihat menjelang terjadinya krisis keuangan dan perbankan serta krisis lainnya. Bila fenomena umum muncul, maka peluang terjadinya krisis keuangan menjadi tinggi, peluang atau kemungkinan krisis keuangan 
sebenarnya dapat diramalkan, yaitu dengan melihat berbagai indikator dini yang tepat.

Dengan melihat krisis keuangan dan perbankan tahun 1997 mempunyai akibat terhadap beban fiskal yang hampir Rp 650 triliun, akibat tak langsung terhadap restrukturisasi di berbagai sektor keuangan yang belum selesai sampai saat ini. Seperti meningkatnya jumlah penduduk miskin, ketimpangan ekonomi, menurunnya kegiatan ekonomi, membuat sistem peringatan dini sangat penting untuk dilakukan guna mengantisipasi terjadinya krisis di masa datang (Muhammad Handry Irmansyah.2009:3)

Lima belas tahun lebih berbagai model teori krisis keuangan telah dikembangkan untuk melihat gangguan terhadap sistem keuangan atau jatuhnya sistem kurs, sistem perbankan atau pasar modal. Saat yang bersamaan berkembang penelitian empiris deteksi dini untuk memprediksikan krisis keuangan. Dengan mengkaji berbagai teori krisis keuangan dan mengevaluasi terhadap berbagai model yang dikembangkan, nampaknya krisis keuangan dapat dideteksi lebih dini terutama bila kejadian krisis tersebut memiliki pola tertentu. Adanya berbagai model, tidak terdapat kesepakatan mengenai penyebab krisis keuangan. Krisis keuangan Indonesia tidak dapat diperkirakan dengan tepat dengan model umum yang dikembangkan oleh para peneliti seperti Kaminsky, Lizondo, dan Reihart (1998), Goldstein, Kaminsky dan Reihart (2000) serta Zhuang (2005). Model logit oleh Rose dan Frankel (1996), model signal oleh Rose dan Wyplosz (1996).

Model khusus untuk suatu negara perlu dikembangkan berdasarkan keunikan perekonomian suatu negara yang tidak dapat dideteksi dengan model umum. Perbandingan karakteristik pasca krisis dan temuan dari model khusus sebuah negara sebelum terjadinya krisis tentunya tidak dikaitkan dengan masalah yang dilihat secara normal jika analisis krisis yang melibatkan sejumlah negara. Analisis lintas negara lebih sulit diinterpretasikan dibanding hanya menyangkut kasus sebuah negara.

$\begin{array}{lrr}\quad \text { Inti dari } & \text { sistem } \\ \text { peringatan dini } & \text { yaitu } \\ \text { mengembangkan } & \text { model }\end{array}$


empirik dengan mengamati sejumlah indikator ekonomi terpilih, maka dapat diramalkan kemungkinan krisis di waktu yang akan datang. Nilai dari sejumlah indikator ini biasanya berbeda, sebelum, selama dan sesudah krisis, sehingga pergerakannya dapat digunakan untuk memperkirakan probabilitas terjadinya krisis keuangan.

Tulisan ini diharapkan
dapat memperkenalkan
berbagai pendekatan yang
dapat digunakan dalam
membuat sistem peringatan
dini krisis keuangan di
Indonesia. Sistem tersebut
harus memberikan cara yang
nmemuaskan dalam memilih
indikator-indikator dini yang
memberikan peringatan
menjelang terjadinya krisis
keuangan sehingga dapat
mengantisipasi krisis yang
akan terjadi, dan sangat
bermanfaat untuk mengelola
kebijakan ekonomi. Model
peringatan dini memberikan
gambaran mengenai terjadinya
gangguan dalam
perekonomian, sehinga
memberikan potensi akan
terjadinya krisis dalam kurun
waktu tertentu. Model
peringatan dini dapat
dipergunakan untuk melihat
kinerja perekonomian di masa
tenang. Krisis Indonesia yang

terjadi pada tahun 1971 - 1975 sebagai sampel untuk memprediksi krisis Indonesia tahun 1997, hasilnya secara umum cukup memuaskan atau memberikan signal dengan probabilitas yang tinggi akan terjadi krisis di Indonesia pada tahun 1997, bahkan terjadinya krisis kecil tahun 2005.

\section{TEORI KRISIS KEUANGAN}

1. Definisi Krisis Keuangan

Krisis keuangan secara umum didefinisikan sebagai jatuhnya nilai mata uang domestik terhadap mata uang asing utamanya mata uang dollar Amerika Serikat. Eichengreem, Rose dan Wyplosz mendefinisikan krisis sebagai tekanian pasar terhadap kurs.

KLR (Kaminsky, Lizondo dan Reinhart) mendefinisikan krisis keuangan jika indeks krisis melebihi 3 kali standar deviasinya terhadap rata-rata (mean). Sedangkan Bank Dunia mendefinisikan krisis keuangan bila indeks krisis melebihi 1,5 kali dari standar deviasi terhadap rata-rata

2. Penyebab Krisis Keuangan

Krisis keuangan dan perbankan secara umum 
sering terjadi di berbagai belahan dunia. Pemahaman tentang penyebab terjadinya krisis keuangan masih sangat beragam bergantung pada keadaan negara yang dijadikan kasus. Pola atau karakteristik krisis keuangan di berbagai negara adalah tertentu dan berulang. Oleh karenya pemahaman tentang pola umum dan penyebab dari krisis keuangan yang terjadi selama ini akan memberikan landasan teori untuk membuat suatu ciri-ciri umum sebuah krisis keuangan. Radelet dan Sachs (1998) membedakan menjadi 4 bagian teori, yaitu teori generasi pertama krisis keuangan, teori generasi kedua krisis keuangan, teori generasi ketiga krisis keuangan dan teori di luar sistem generasi

3. Tipologi Keuangan

Menurut Radelet dan Sachs (1998) secara teoritis krisis keuangan berdasarkan sebabnya dibagi menjadi beberapa tipologi

a. Kebijakan Ekonomi Yang Tidak Konsisten

Krisis disebabkan oleh seperangkat kebijakan makro yang tidak konsisten. Dari krisis neraca pembayaran mendorong krisis finansial yang diawali dengan jatuhnya kurs mata uang akibat ekspansi kredit domestik oleh Bank Sentral yang tidak konsisten dengan target nilai tukar mata uang. Biasanya negara menggunakan sistem nilai tukar tetap - (Page Exchange Rate).

Krisis terjadi karena pemerintah melakukan devaluasi guna meningkatkan devisa yang sedang menurun. Mata uang domestik overvaluation terhadap mata uang asing, daya saing harga barang ekspor menurun, ekspor melambat, impor naik karena harga barang impor lebih murah. Hal ini menyebabkan neraca transaksi berjalan defisit. Jika terjadi capital in flow, pinjaman luar negeri masuk dan investasi portofolio, maka keadaan secara umum aman. Namun jika hal tersebut tidak terjadi, maka cadangan devisa akan terkuras untuk mempertahankan nilai tukar tetap, dan guna menjaga stabilitas dilakukan devaluasi agar cadangan devisa meningkat. Model ini 
dikenal dengan model generasi pertama. Menurut Obsfeld, lemahnya struktur dan daya saing ekspor akibat sistem keuangan yang lemah dan lambatnya produktivitas akan terjadi percepatan krisis (self fulfilling crisis). Indikasi terjadinya krisis neraca pembayaran karena ekspansi kredit yang berlebihan dalam nilai tukar tetap (peg exchange rate system) yang dibarengi defisit anggaran belanja pemerintah. Keadaan semacam ini cadangan devisa bisa habis oleh serangan spekulasi.

b. Kepanikan Pasar Uang Penyebab krisis karena penarikan besar-besaran atas dana "kredit yang diberikan kreditor asing, terutama pinjaman jangka pendek secara mendadak, sehingga mengakibatkan kekurangan likuiditas terhadap mata uang asing (cadangan devisa). Masa panik ini, setiap orang berlomba menarik uangnya di pasar dengan mengonversikan ke dalam mata uang asing. Mereka menghindari turunnya aset yang dimiliki, sehingga mata uang domestik semakin jatuh (flight to quality)

c. Pecahnya gelembung finansial (financial buble) Ini terjadi karena spekulasi membeli aset keuangan pada tingkat harga di atas harga fundamental dengan harapan mendapatkan capital gain. Bila pelaku pasar mulai menyadari bubble, maka krisis mulai terjadi artinya krisis terdeteksi. Pelaku pasar akan menjual seluruh aset yang dimiliki dengan menukarkannya dalam mata uang asing, maka nilai mata uang domestik mulai jatuh.

\section{d. Moral Hazard}

Dengan adanya jaminan pemerintah dan lemahnya aturan, maka moral hazard akan terjadi. Penyebabnya adalah investasi yang berlebihan dan berisiko oleh perbankan dan lembaga keuangan yang dapat meminjam kredit, dan hutang mereka melebihi modal yang dimiliki (Akerlof dan Romer 1993). Kreditor asing dan domestik memberi kredit yang berisiko tinggi karena tahu pemerintah dan lembaga keuangan asing akan memberikan 
talangan jika terjadi masalah. Krugman menerapkan ini untuk melihat krisis keuangan di Asia pada tahun 1997.

e. Ketiadaan Aturan Baku

Tidak terdapatnya sistem kebangkrutan/kepailitan di mana korporasi mengalami masalah likuiditas, merupakan salah satu penyebab krisis, karena bertautan erat dengan pemegang aset-aset yang harus dilikuidasi (Sachs, Miller dan Zhang 1997). Tidak adanya cara dalam menata ulang tagihan kasus likuiditas internasional maka akan mengakibatkan kredit macet. Menurut Berg dkk. Penyebab krisis keuangan dibedakan menjadi dua, yaitu gangguan terhadap fundamental ekonomi (inflasi, peertumbuhan ekonomi, dan neraca pembayaran) dan serangan spekulasi yang mempercepat krisis (self fulfilling crisis).

Pengamatan McKinnon dan Pill, H. faktor penyebab krisis yaitu peranan aliran modal dalam perekonomian dan sektor perbankan yang tidak teratur, serta asuransi deposito dan masalah moral hazard di perbankan (Anggito A. dan M. Handry Imansyah. 2008). ' Kredit yang berlebihan menyebabkan

overinvestment, sehingga inflasi cenderung tinggi akan menghilangkan daya saing dan menekan pertumbuhan ekonomi, diperberat kredit yang tersalur ke sektor non tradable.

4. Model Generasi Pertama Krisis Keuangan

Krugman-lah orang pertama yang secara formal menyajikan analisis krisis keuangan atau krisis neraca pembayaran. Model ini merupakan pengembangan model Salant dan Henderson (1978) yang menjelaskan perilaku emas. Misalnya spekulasi membeli terus mata uang asing dengan mata uang domestik sampai cadangan devisa menipis, kemudian pemerintah akan melakukan devaluasi untuk menjaga cadangan devisa dan kurs. Model ini dengan krisis dari aspek fiskal.

Model ini terjadi karena kebijakan pemerintah tidak konsisten dalam bidang moneter dan fiskal dalam nilai tukar tetap. Pemerintah menjalankan anggaran defisit dengan pembiayaan ekspansi kredit dari Bank Sentral. Jumlah uang 
beredar kelebihan likuiditas, sehingga inflasi tinggi. Kelebihan likuiditas akan dikonversikan ke mata uang asing, maka permintaan mata uang asing meningkat. Bila inflasi di negara mitra dagang relatif rendah, maka mata uang domestik mengalami overvalued dan diikuti oleh serangan spekulasi terhadap mata uang asing.

Keberhasilan model generasi pertama, adalah kemampuannya dalam memperkirakan momentum serangan spekulasi ketika cadangan devisa tiba-tiba turun drastis karena investor tidak menunggu jatuhnya sistem kurs melalui habišnya cadangan devisa. Model Krugman ini sederhana, sehingga berbagai modifikasi dan perbaikan dengan menambah asumsi dan karakteristik krisis keuangan. Misalnya; rendahnya kredibilitas sistem kurs, kekauan harga, ketidak pastian mènangani serangan spekulasi, ketidak pastian ekspansi kredit, perubahan sistem kurs, kebijakan sterilisasi, runtuhnya sistem kurs tetap, tingginya utang luar negeri, control lalu-lintas modal agar mendekati sistuasi real. Pemerintah yang diasumsikan pasif adalah tidak realistis (kelemahan model ini), Pemerintah dan Bank Sentral melakukan berbagai kebijakan untuk memperbaiki kinerja perekonomian.

5. Model Generasi Kedua Krisis Keuangan

Krisis keuangan tahun 1992 dalam Sistem Moneter Eropa (Europen

Monetary

System/EMS) tidak dapat dijelaskan dengan model generasi pertama. Penyebab krisis dalam EMS tidak saja disebabkan oleh kebijakan ekonomi negara-negara Eropa dan keputusan perubahan sistem kurs yang tidak didukung oleh cadangan devisa yang memadai. Tetapi juga peran Inggris dan Perancis yang ragu-ragu, meningkatnya pengangguran serta naiknya suku bunga

Untuk menjelaskan krisis EMS maka dikembangkan model baru yang dikenal dengan model krisis generasi kedua. Kurs tetap dipertahankan, jika masih mempunyai tujuan tertentu (misalnya mengendalikan inflasi) walaupun menghasilkan dampak negatif yang tidak diinginkan terhadap variabel ekonomi. Sehingga keputusan untuk membiarkan sistem kurs tergantung pada analisis 
manfaat (contohnya manfaat diturunkan dari teori optimum currency area) dan biaya untuk mempertahankan kurs tetap pada saat pengangguran yang tinggi, kesulitan sektor perbankan, tingginya utang publik, dan lain sebagainya. Keadaan ini lebih realistis, dibanding model generasi pertama yang mengasumsikan perilaku mekanis otoritas sebagai lawan dari perilaku rasional pelaku pasar (Saqib, 2002). Semua kebijakan ekonomi merupakan faktor eksogen, perubahan ekspektasi pelaku pasar mendorong keseimbangan lebih dari satu, sehingga serangan spekulasi terhadap mata uang mempercepat krisis (self fulfilling).

Penyebab dalam model generasi kedua dapat diikuti dari dua arah dan tipe dari rangkaian yang menghasilkan lebih dari satu keseimbangan dan spekulasi saling mepercepat. Perubahan sistem kurs akan menyebabkan variabel mengubah kenaikan biaya untuk mempertahakan sistem kurs. Bila biaya terlalu mahal, pembuat kebijakan akan memutuskan devaluasi mata uang. Otorita moneter kurang berminat untuk mempertahankan kurs dengan tingkat bunga tinggi dalam serangan spekulasi, karena akan meningkatkan pengangguran. Tingginya utang publik akan meningkatkan biaya mempertahankan sistem kurs, dan akan mendorong serangan spekulasi. Jika sistem kurs dipertahankan dengan menaikkan suku bunga, maka akan memicu krisis perbankan, dan mendorong untuk mengubah sistem kurs tetap.

Implikasi utama dari model generasi kedua adalah bahwa krisis keuangan tidak dapat dijelaskan hanya sebagai akibat perubahan fundamental ekonomi. Penekanan ide ini ketika perubahan dalam fundamental ekonomi adalah sebuah kondisi yang diperlukan untuk memicu krisis keuangan. Peranan kunci dalam model generasi kedua dimainkan oleh perubahan ekspektasi sebagai penyebab utama krisis keuangan. Isu penting yang belum terpecahkan oleh model generasi kedua yaitu sinergi jatuhnya kepercayaan terhadap mata uang dengan ekspektasi serta aksi spekulasi yang menyerang secara mendadak terhadap mata uang. 
6. Model Generasi Ke Tiga Krisis Keuangan

Kelompok tiga dari model ini menyatakan

bahwa

penyebab kfisis keuangan adalah efek penularan (contagion effect) melalui hubungan perdagangan. Ketika depresi terjadi di suatu negara menjadikan penurunan daya saing untuk negara lain. Ketergantungan antar-negara akan memberikan peranan dari sebuah krisis ketika ketidak mampuan suatu negara untuk membayar utang luar negerinya, kreditor asing mencabut pinjamannya di negara lain. Sehingga krisis keuangan di sebuah negara berperan terhadap memburuknya persepsi dari suatu sistem ekonomi di negara lain yang mempunyai karakteristik mirip.

7. Model di Luar Sistem

Dari berbagai model krisis keuangan yang paling penting yang berada di luar sistem generasi adalah model Kindleberger-Minsky, yang menjelaskan tiga tahapan dalam krisis keuangan: mania, panik, dan runtuh (collapse). Mania adalah periode upswing dalam siklus bisnis ketika pelaku pasar merestruktur aser-aset mereka yang lebih mengarah pada aset finansial dan riil. Panik dicirikan oleh pengaruh dorongan dan persaingan dalam transformasi aset finansial dan riil dalam bentuk asset yang paling likuid sedangkan runtuh (collapse) adalah tahap akhir dari proses.

\section{IV.MACAM-MACAM MODEL} EMPIRIS KRISIS KEUANGAN 1. Model Pendeteksian Krisis Keuangan Model yang konvensional adalah model parametricl ekonometrik dengan analisis probit/ logit. Menjelang terjadinya krisis di Asia dikembangkan model signal atau model non parametrik. Kemudian juga dikembangkan model jaringan saraf buatan, model hibrida, dan pendekatan sederhana makroprudensial dan mikroprudensial yang diadopsi oleh IMF dan ADB.

2.Pendekatan

Signal Pendekatan signal dikategorikan sebagai pendekatan non parametrik. Model ini menggunakan berbagai indikator yang saling berhubungan secara bersama-sama untuk memberikan signal pada periode menjelang terjadinya krisis. 
3.Pendekatan Ekonometrik (Probit/logit) Pendekatan ekonometrik . ini dipergunakan oleh: Eichengreen, Rose dan Wyplosz (1996), Frankel dan Rose (1996), Klein dan Morion (1997) Berg dan Patillo (1999).

Frankel dan Rose menggunakan ekuasi sbb.

$$
Y_{i}=\square+\sum \square_{1} x_{1}+L_{i=1}^{16}
$$

$y_{i}=1$ bila terjadi krisis

$y_{i}=0$ bila tidak terjadi krisis

$$
\begin{aligned}
& x_{1}=16 \text { indikator } \\
& \mathrm{D}_{1}=\text { error term }
\end{aligned}
$$

\section{Pendekatan Jaringan Saraf Buatan}

Model ini dapat menghitung atau memprediksi bedasarkan proses informasi dan identifikasi pola yang diolah oleh jaringan saraf buatan (Zhang.2004). Model jaringan saraf buatan dapat didefinisikan sebagai arsitektur computer di mana sejumlah prosesor saling tehubung seperti halnya pada neuron dan mempunyai kemampuan untuk belajar melalui proses trial and error.

Di bidang keuangan, model ini sudah banyak digunakan untuk memprediksi saham, kurs, atau potensi kebangkrutan perusahaan. Kelebihan model ini: mudah membuatnya, dapat menangani data besar tak beraturan, dan dapat menyelesaikan masalah non linier.

\section{Pendekatan Makro dan} Mikro Prudential.

Model ini terutama dipergunakan untuk melihat kestabilan sektor perbankan dan keuangan yang pada awalnya dipergunakan oleh IMF an ADB. Kelemahan model ini tidak mampu mengetahui potensi risiko secara tepat yang akan berakibat pada krisis keuangan. Inti pendekatan ini adalah kehati-hatian pada indikator-indikator tertentu bila indikator ini menunjukkan abnormalitas, sehingga pembuat kebijakan harus berhati-hati. Fungsi pendekatan ini sebagai alat bantu untuk sistem peringatan dini (Early Warning System/EWS) dan 
mengindeptifikasi kesehatan perekonomian.

\section{KRISIS KEUANGAN DI INDONESIA}

\section{Model Yang Dikembangkan}

Dalam bagian lima ini akan akan dibahas hasil setiap model yang dikembangkan seperti model signal, model logit dan model jaringan saraf buatan untuk krisis keuangan di Indonesia. Setiap model akan dilihat kinerjanya dalam meramalkan krisis keuangan baik dalam sampel maupun di luar sampel. Namun dalam kadar tertentu model logit yang kurang memuaskan, dibandingkan dengan model signal dan model jaringan saraf buatan.

\section{Model Signal}

a. Periode Krisis

Periode Krisis Keuangan selama tahun 19711997 ada 4 kali. Batas ambang yang digunakan adalah rata-rata Indeks Krisis ditambah 2 standar deviasi.

Tabel 1 : Periode Krisis Keuangan di Indonesia 1971 - 1997

\begin{tabular}{|c|c|c|c|c|}
\hline No. & Studi Inti & GKR $^{*}$ & ZHUANG $^{*}$ & EDISON $^{*}$ \\
\hline 1 & Nov-1978 & Nov-1978 & Nov-1978 & Nov-1978 \\
\hline 2 & Apr-1983 & Apr-1983 & Apr-1983 & Apr-1983 \\
\hline 3 & Sep -1986 & Sep -1986 & Sep -1986 & Sep -1986 \\
\hline 4 & Agus-1997 & & Des - 1997 & \\
\hline
\end{tabular}

Sumber: Zhuang (2005) tabel 4.4

Dalam penelitian ini, indeks krisis hanya menggunakan indikator nilai tukar rupiah terhadap dolar AS. dengan batas ambang 2 kali standar deviasi di atas rata-rata.

b. Memilih Indikator Dini
Dalam studi krisis keuangan indikator yang digunakan sangat beragam dari berbagai sektor ekonomi. Kolom pertama tabel 2 menunjukkan kecenderungan indikator tunggal memberikan signal yang baik $(A \wedge+C)$. Kolom kedua pada tabel 2 menunjukkan besarnya rasio pengganggu signal (noise to signal ratio/NSR). Jika nilai 
dalam kolom ini lebih rendah maka Semakin besar angka indek komposit, akan lebih baik cetirus paribus. semakin besar pula probabilitas suatu Kolom ketiga adalah probabilitas negara akan mengalami krisis dalam kondisional dari indikator dini yang 24 bulan kemudian.

memberikan signal selama masa pengamatan. Sedangkan kolom d. Kinerja Model

keempat jumlah observasi setiap indikator dini.

1) Peramalan Dalam Sampel

Indikator yang baik adalah bila memiliki NSR yang rendah. Ada trade off dalam menggunakan jumlah indikator dini yang dipilih. Pertama, Bila jumlah indikator dini yang digunakan lebih banyak, maka membutuhkan jumlah data indikator dini yang relatif besar, dan bisa saja terjadi indikator dini tersebut sudah terwakili oleh indikator dini yang lain. Kedua, Bila menggunakan indikator dini yang relatif sedikit, akan momudahkan dalam kebutuhan data dan lebih praktis dari segi operasional. Akan tetapi informasi sektor ekonomi yang lebih detail jika terjadi gangguan tidak terserap.

Memasukkan efek penularan (contagion effect), bila terjadi krisis keuangan di negara lain, periode pra krisis (window period) dipilih 24 bulan agar hasilnya memuaskan.

c. Indeks Komposit dan Probabilitas Krisis Keuangan

Hasil perhitungan indeks kompoisit ini tidak dapat secara langsung digunakan untuk memprediksi krisis. Indeks komposit harus ditransformasikan ke dalam bentuk probabilitas terjadinya krisis keuangan.
Pendekatan nonparametrik dalam meramalkan probabilitas krisis tidak memiliki alat uji hipotesis apakah nilai peramalan tersebut signifikan atau tidak. Kemampuan peramalan dapat dievaluasi dalam ketepatan dan kalibrasinya. Peramalan probabilitas dapat diukur kinerjanya dengan mengukur rata-rata penyimpangan kuadrat (mean squared error), skor probabilitas kuadrat (quadratic probability Score/QPS). Sementara itu untuk mengukur ketepatan kalibrasi peramalan juga diukur dengan global squared bias (SGB). Ketepatan peramalan probabilitas akan terjadi krisis keuangan adalah proporsi pengamatan yang secara tepat meramalkan periode krisis dan masa tidak krisis akan dapat diukur.

Formulasi skor probabilitas kuadrat (QPS) adalah:

OSS $=\frac{1}{T} \sum_{:=1}^{2}=F 1-F 1:$

Di mana :

$\mathrm{P}=$ Peramalan 
$\mathrm{R}=$ Realisats $\mathrm{i}$

$\mathrm{T}=$ Periode

QPS memiliki rentang $0-2$, bila skor 0 mencerminkan sangat akurat. Sementara itu, kalibrasi dari permaalahan probabilitas berkaitan dengan ketepatan peramalan probabilitas dan frekuensi relatif yang di amati. Kalibrasi membandingkan peramalan probabilitas rata-rata dengan realisasi rata-rata.

Formulasinya : $\mathrm{GSB}=2$ $(\dot{P}-\bar{R})^{2}$

$P=\frac{1}{T} \sum_{i=1}^{1} P r$ dan $\bar{R}=\frac{1}{T} \sum_{t=1}^{1} R t$

Nilai GSB memiliki rentang dari $0-2$, dengan nilai skor 0 kalibrasinya sempurna.
Peramalan

dengan menggunakan indek komposit 1 (IK 1) menunjukkan kinerja yang lebih baik dibanding dengan indek koposit 2 (IK 2) dalam meramalkan probabilitas krisis. Hasil ramalan probabilitas dari IK 1 menerapkan NSR $\leq 0.75$, di mana semakin rendah NSR semakin sedikit indikator yang terpilih untuk menjadi indikator dini dalam memberikan signal dan diharapkan semakin baik.

Dengan memperhatikan tabel 2, kita bisa mengetahui indikator mana saja yang memiliki persentase tinggi dalam ketepatan prediksi, dan probabilitas kondisional krisis serta NSR yang minimal.

Tabel 2: Kinerja Indikator Dini

\begin{tabular}{|c|l|r|r|r|c|}
\hline \multicolumn{2}{|c|}{ INDIKATOR } & $\begin{array}{c}\text { Ketepatan } \\
\text { Prediksi } \\
\text { (ANA+C) } \\
\text { DIm \% }\end{array}$ & $\begin{array}{c}\text { Rasio } \\
\text { Pengganggu } \\
\text { Signal (NSR) }\end{array}$ & $\begin{array}{c}\text { Probabilitas } \\
\text { Kondisional } \\
\text { Krisis (AA+B) } \\
\text { DIm \% }\end{array}$ & $\begin{array}{c}\text { Jumlah } \\
\text { Sampel }\end{array}$ \\
\hline No & $\begin{array}{l}\text { Neraca Transaksi } \\
\text { Berjalan }\end{array}$ & & & & 300 \\
\hline 1 & $\begin{array}{l}\text { Nilai tukar rii Rp/US\$ } \\
\text { (devisa thd trend) }\end{array}$ & 58.33 & 0.07 & 82.35 & 300 \\
\hline 2 & $\begin{array}{l}\text { Impor (perubahan } \\
\text { tahunan) }\end{array}$ & 5.56 & 1.82 & 14.81 & 300 \\
\hline 3 & $\begin{array}{l}\text { Ekspor (perubahan } \\
\text { tahunan) }\end{array}$ & 9.72 & 0.41 & 43.75 & 300 \\
\hline 4 & $\begin{array}{l}\text { Rasio cadangan } \\
\text { devisa dengan impor }\end{array}$ & 19.44 & 0.63 & 33.33 & 300 \\
\hline
\end{tabular}




\begin{tabular}{|c|c|c|c|c|c|}
\hline & Neraca Modal & & & & \\
\hline 5 & $\begin{array}{l}\text { Rasio tagihan di BIS } \\
\text { dg cadangan devisa }\end{array}$ & 8.33 & 1.63 & 16.22 & 300 \\
\hline 6 & $\begin{array}{l}\text { Rasio M2 dengan } \\
\text { cadangan devisa }\end{array}$ & 33.33 & 0.53 & 37.50 & 300 \\
\hline 7 & $\begin{array}{l}\text { Rasio investasi PDB } \\
\text { dengan PDB }\end{array}$ & 12.50 & 0.84 & 27.27 & 300 \\
\hline 8 & Cadangan devisa & 8.33 & 0.58 & 35.29 & 300 \\
\hline 9 & $\begin{array}{l}\text { Rasio aliran modal jk } \\
\text { pendek dengan PDB }\end{array}$ & 12.50 & 0.93 & 26.47 & 285 \\
\hline 10 & $\begin{array}{l}\text { Spread tingkat bunga } \\
\text { riil }\end{array}$ & 19.44 & 0.57 & 40.00 & 258 \\
\hline \multirow[t]{2}{*}{11} & $\begin{array}{lll}\text { Rasio hutang luan } \\
\text { negeri \& cadangan } \\
\text { devisa }\end{array}$ & 41.67 & 0.42 & 46.51 & 176 \\
\hline & Sektor Keuangan & & & & \\
\hline 12 & $\begin{array}{l}\text { Tingkat bunga riil } \\
\text { tabungan }\end{array}$ & 33.33 & 0.40 & 48.98 & 257 \\
\hline 13 & $\begin{array}{l}\text { Rasio tingkat bunga } \\
\text { pinjaman \& tabungan }\end{array}$ & 20.00 & 0.76 & 5.56 & 114 \\
\hline 14 & $\begin{array}{l}\text { M2 multiplier } \\
\text { (perubahan tahunan) }\end{array}$ & 15.28 & 0.60 & 34.38 & 300 \\
\hline 15 & $\begin{array}{l}\text { Rasio kredit dengan } \\
\text { PDB (perub. tahunan) }\end{array}$ & 23.61 & 0.24 & 56.67 & 300 \\
\hline \multirow[t]{2}{*}{16} & $\begin{array}{ll}\text { Simpanan } & \text { di } \\
\text { perbankan } & \\
\end{array}$ & 12.50 & 0.84 & 27.27 & 284 \\
\hline & Sektor Riil & & & & \\
\hline \multirow[t]{2}{*}{17} & $\begin{array}{l}\text { PDB riil (perubahan } \\
\text { tahunan) }\end{array}$ & 70.83 & 1.23 & 20,48 & 300 \\
\hline & Sektor Fiskal & & & & \\
\hline 19 & $\begin{array}{l}\text { Rasio konsumsi } \\
\text { pemerintah dan PDB }\end{array}$ & 19.44 & 0.52 & 37,84 & 300 \\
\hline \multirow[t]{2}{*}{21} & $\begin{array}{l}\text { Rasio deficit fiscal } \\
\text { dengan PDB }\end{array}$ & 25.00 & 0.56 & 36,00 & 300 \\
\hline & Ekonomi Global & & & & \\
\hline 20 & $\begin{array}{l}\text { Efek penularan } \\
\text { (contagion) }\end{array}$ & $27.78 \%$ & 0.74 & 29,855 & 300 \\
\hline 21 & Hanrga minyak & $90,28 \%$ & 0,46 & $40.88 \%$ & 300 \\
\hline
\end{tabular}

\footnotetext{
Sumber: Muhammad Handry Imansyah (2009)
} 
Tabel 3 di bawah (halaman berikut) menunjukkan ketepatan dan nilai kalibrasi peramalan probabilitas dalam sampel mencakup periode Januarii 1971 - Desember 1975.
Semua ukuran mengindikasikan tingginya daya prediksi dengan batas ambang probabilitas pada tingkat 30 persen.

Tabel 3: Evaluasi Model NSR $\leq 1,5$ Krisis Keuangan 1971 - 1995

\begin{tabular}{|c|c|c|}
\hline BATAS PROBABILITAS $30 \%$ & KOMPOSIT 1 & KOMPOSIT 2 \\
\hline NSR & 0.1905 & 0.2419 \\
\hline $\begin{array}{l}\text { Jumlah bulan pra krisis yg } \\
\text { diprediksi dg tepat }\end{array}$ & 58 & 43 \\
\hline $\begin{array}{l}\% \text { periode pra-krisis yg member } \\
\text { signal }[A A+C]\end{array}$ & $75,32 \%$ & $59,72 \%$ \\
\hline$\%$ signal salah $[\mathrm{B} / \mathrm{B}+\mathrm{D}]$ & $14,32 \%$ & $14.47 \%$ \\
\hline QPS & 0.3423 & 0.4161 \\
\hline GSB & 0.0556 & 0.0004 \\
\hline $\begin{array}{ll}\text { Ketepatan } & \text { Prediksi } \\
{[(A+D /(A+B+C+D)]} & \\
\end{array}$ & $83.00 \%$ & $79.33 \%$ \\
\hline BATAS PROBABILITAS $40 \%$ & & \\
\hline NSR & 0.1051 & 0.0740 \\
\hline $\begin{array}{l}\text { Jumlah bulan pra-krisis yg } \\
\text { diprediksi dg tepat }\end{array}$ & 46 & 17 \\
\hline $\begin{array}{l}\text { \% periode pra-krisis yg member } \\
\text { signal }[A \wedge A+C]\end{array}$ & $59.74 \%$ & $23,61 \%$ \\
\hline$\%$ Signal Salah $[B /(B+D)]$ & $6.28 \%$ & $1.75 \%$ \\
\hline QPS & 0.3020 & 0.3960 \\
\hline GSB & 0.1701 & 0.0578 \\
\hline $\begin{array}{ll}\text { Ketepatan } & \text { Prediksi } \\
{[(A+D /(A+B+C+D)]} & \\
\end{array}$ & $85,00 \%$ & $80.33 \%$ \\
\hline BATAS PROBABILITAS $50 \%$ & & \\
\hline NSR & 0.1051 & 0.0000 \\
\hline $\begin{array}{l}\text { Jumlah bulan pra-krisis yg } \\
\text { diprediksi dg tepat }\end{array}$ & 46 & 0 \\
\hline $\begin{array}{l}\text { \% periode pra-krisis yg member } \\
\text { signal }[A \cup A+C]\end{array}$ & $59.74 \%$ & $0.00 \%$ \\
\hline \% Signal Salah $[B /(B+D)]$ & $6.28 \%$ & $0.00 \%$ \\
\hline QPS & 0.3020 & 0.4832 \\
\hline GSB & 0.1701 & 0.1152 \\
\hline $\begin{array}{l}\text { Ketepatan } \\
{[(A+D /(A+B+C+D)]}\end{array}$ & $85,00 \%$ & $76.00 \%$ \\
\hline
\end{tabular}

Sumber: Anggito A. dan M. Handry I. (2008) 
2). Peramalan di Luar Sampel

Periode setelah Desember 1995 dapat dipergunakan untuk menilai daya ramal dari model yang dikembangkan terutama untuk krisis keuangan 1997. Periode ini merupakan periode di luar sampel. Ada 2 macam indeks

komposit yang $\begin{aligned} & \text { dapat }^{*} \\ & \text { dalam }\end{aligned}$
dipergunakan

meramalkan probabilitas krisis di masa datang terutama krisis keuangan 1997. Ketepatan peramalan cukup memadai 83,33 persen (tabel 4). Dari signal memberikan peringatan dari total 100 persen selama 24 bulan sebelum terjadinya krisis dengan batas ambang probabilitas sama dengan atau di atas 30 persen.

Tabel 4: Evaluasi Model NSR $\leq 1,5$ Krisis Keuangan $1996-2000$

\begin{tabular}{|l|c|c|}
\hline \multicolumn{1}{|c|}{ BATAS PROBABILITAS 30\% } & $\begin{array}{c}\text { KOMPOSIT } \\
1\end{array}$ & $\begin{array}{c}\text { KOMPOSIT } \\
2\end{array}$ \\
\hline $\begin{array}{l}\text { NSR } \\
\text { Jumlah bulan pra krisis yg diprediksi dg } \\
\text { tepat }\end{array}$ & 0.0486 & 0.1536 \\
\hline $\begin{array}{l}\% \text { periode pra-krisis yg member signal } \\
\text { [A }\end{array}$ & 20 & 13 \\
\hline$\%$ signal salah [B/B+D] & $83,33 \%$ & $54,17 \%$ \\
\hline QPS & $4,05 \%$ & $8,33 \%$ \\
\hline GSB & 0.6239 & 0.3119 \\
\hline Ketepatan Prediksi [(A+D/(A+B+C+D)] & 0.000 & 0.4201 \\
\hline \multicolumn{1}{|c|}{ BATAS PROBABILITAS 40\% } & $92.86 \%$ & $76,67 \%$ \\
\hline NSR & 0.1051 & 0.0740 \\
\hline $\begin{array}{l}\text { Jumlah bulan pra-krisis yg diprediksi dg } \\
\text { tepat }\end{array}$ & 46 & 17 \\
\hline $\begin{array}{l}\% \text { periode pra-krisis yg member signal } \\
\text { [AA+C] }\end{array}$ & $59.74 \%$ & $23.61 \%$ \\
\hline$\%$ Signal Salah [B/(B+D)] & $6.28 \%$ & $1.75 \%$ \\
\hline QPS & 0.3020 & 0.3960 \\
\hline GSB & 0.1701 & 0.0578 \\
\hline Ketepatan Prediksi [(A+D/(A+B+C+D)] & $85,00 \%$ & $80.33 \%$ \\
\hline BATAS PROBABILITAS 50 \% & & \\
\hline NSR & 0.1051 & 0.0000 \\
\hline Jumlah bulan pra-krisis yg diprediksi dg & 46 & 0 \\
\hline
\end{tabular}




\begin{tabular}{|l|c|c|}
\hline tepat & & \\
\hline $\begin{array}{l}\text { \% periode pra-krisis yg member signal } \\
{[\mathrm{AA}+\mathrm{C}]}\end{array}$ & $59.74 \%$ & $0.00 \%$ \\
\hline$\%$ Signal Salah [B/(B+D)] & $6.28 \%$ & $0.00 \%$ \\
\hline QPS & 0.3020 & 0.4832 \\
\hline GSB & 0.1701 & 0.1152 \\
\hline Ketepatan Prediksi [(A+D/(A+B+C+D)] & $85,00 \%$ & $76.00 \%$ \\
\hline
\end{tabular}

Sumber: Anggito A. dan M. Handry I. (2008)

Mengapa ketiga model tersebut berbeda dalam memberikan signal terhadap potensi atau risiko terjadinya krisis keuangan pada tahun 2008. Makin tinggi NSR yang dipakai, semakin banyak pula indikator yang dipakai. Maknànya semakin kecil bobot dari setiap indikator dalam pembentukan indeks komposit. Jika jumlah indikator yang memiliki pola abnormal relatif sama, maka jumlah indeks komposit yang terbentuk tidak terlalu besar, sehingga indeks komposit belum mencapai batas tertentu untuk membangkitkan signal.

3. Model Logit Krisis Keuangan. Berbagai model logit yang di eksplorasi, masa pra-krisis 24 bulan adalah yang terbaik. Artinya semua tanda hasil estimasi indikator dini menunjukkan sesuai dengan teori, walaupun ada 2 indikator dini yang tidak signifikan pada tingkat alpha $5 \%$. Indikator yang signifikan itu adalah ekspor, nilai tukar riil (real exchange rate $/ R E R$ ) proporsi konsumsi pemerintah terhadap PDB dan cadangan devisa. Sedangkan yang tidak signifikan yaitu pertumbuhan PDB, provorsi investasi terhadap PDB dan pertumbuhan rasio kredit terhadap PDB (perhatikan tabel 5 di bawah ini)

Tabel 5: Hasil Estimasi. Model Logit Dengan Masa Pra-krisis 24 Bulan 19711995

\begin{tabular}{|l|r|r|r|r|}
\hline \multicolumn{1}{|c|}{ Indikator } & Koefisien & $\begin{array}{c}\text { Std. } \\
\text { Error }\end{array}$ & z-Statistik & Probabilitas \\
\hline Konstanta & -25.8809 & 4.5396 & -5.7010 & 0.0000 \\
\hline Pertumbuhan PDB & -4.7363 & 3.8361 & -1.2346 & 0.2170 \\
\hline $\begin{array}{l}\text { Peertumbuhan } \\
\text { Cadangan Devisa }\end{array}$ & 1.4127 & 0.4969 & 2.8427 & 0.0045 \\
\hline Rasio Pertumbuhan & 2.0343 & 1.5887 & 1.2804 & 0.2004 \\
\hline
\end{tabular}




\begin{tabular}{|c|c|c|c|c|}
\hline Kredit terhadap PDB & & & & \\
\hline Pertumbuhan Ekspor & -1.6995 & 0.0088 & -1.8562 & 0.0634 \\
\hline $\begin{array}{l}\text { Kurs Riil (Deviasi } \\
\text { Trend) }\end{array}$ & 0.0487 & 40.7429 & 5.5115 & 0.0000 \\
\hline $\begin{array}{l}\text { Proporsi Konsumsi } \\
\text { Pemerintah Thd PDB }\end{array}$ & 220.1449 & 1.0978 & -0.7995 & 0.0000 \\
\hline $\begin{array}{l}\text { Proporsi Investasi } \\
\text { Terhadap PDB }\end{array}$ & -0.8777 & & & 0.4240 \\
\hline LR Statistik (7 df) & 228.0146 & $\begin{array}{r}M c \\
\text { Fadder }\end{array}$ & Squared & 0.6895 \\
\hline $\begin{array}{l}\text { Probability (LR } \\
\text { Statistik) }\end{array}$ & 0.0000 & & & \\
\hline
\end{tabular}

Sumber: Anggito A.dan N: Handry I. (2008)

Tabel 6: Hasil Estimasi Model Probit dengan Masa Pra-krisis 24 Bulan 1971 1995

\begin{tabular}{|l|r|r|r|r|}
\hline \multicolumn{1}{|c|}{ Indikator } & Koefisien & Std. Error & z-Statistik & Probabilitas \\
\hline Konstanta & -11.6031 & 1.7265 & -6.7205 & 0.0000 \\
\hline Pertumbuhan PDB & -0.7965 & 1.7965 & -0.4482 & 0.6539 \\
\hline $\begin{array}{l}\text { Peertumbuhan } \\
\text { Cadangan Devisa }\end{array}$ & 0.7148 & 0.2483 & 2.8790 & 0.0040 \\
\hline $\begin{array}{l}\text { Rasio Pertumbuhan } \\
\text { Kredit terhadap PDB }\end{array}$ & 0.0699 & 0.7850 & 0.0891 & 0.9290 \\
\hline Pertumbuhan Ekspor & -1.0257 & 0.4604 & -2.2275 & 0.0259 \\
\hline $\begin{array}{l}\text { Kurs Ril (Deviasi } \\
\text { Trend) Konsumsi }\end{array}$ & 0.0199 & 0.0032 & 6.1860 & 0.0000 \\
\hline $\begin{array}{l}\text { Proporsi } \\
\text { Pemerintah Thd PDB }\end{array}$ & 96.4711 & 15.4500 & 6.2440 & 0.0000 \\
\hline $\begin{array}{l}\text { Proporsi Investasi } \\
\text { Terhadap PDB }\end{array}$ & 0.0772 & 0.5826 & 0.1326 & 0.8945 \\
\hline $\begin{array}{l}\text { LR Statistik (7 df) (LR } \\
\text { Sumber: Anggito A.dan M. }\end{array}$ & 218.3984 & \multicolumn{2}{|c|}{ Mc R ${ }^{2}$} & 0.6605 \\
\hline $\begin{array}{l}\text { Probability } \\
\text { Statistik) }\end{array}$ & 0.0000 & & \\
\hline
\end{tabular}

Sumber: Anggito A.dan M. Handry I. (2008)

Model Probit menggunakan fungsi distribusi komulatif standar normal, sedangkan model Logit menggunakan fungsi logistik. Secara umum kedua model ini hasilnya tidak jauh berbeda, namun model logistik memiliki koefisien yang nilai dan arahnya sesuai dengan teori walaupun ada yang tidak signifikan pada alpha $5 \%$. 


\section{Kinerja Model "}

Model ini cukup memadai untuk meramalkan krisis Indonesia 1997 dalam memberikan peringatan, walaupun probabilitas meningkat hanya satu tahun menjelang krisis. Jika dilihat dari aspek periode prakrisis probabilitas akan muncul satu tahun menjelang krisis, sementara periode pra-krisis seharusnya muncul dua tahun menjelang krisis keuangan. Kinerja model logit atau probit dapat dilinat dari nilai McFadden $R^{2}$. Semakin tinggi nilai McFadden $R^{2}$, semakin baik. Namun indikator lain juga dapat digunakan seperti menghitung ratarata penyimpangan kuadrat (mean squared error), skor probabilitas kuadrat (quadratic probability score/QPS) seperti pada model non parametrik.

Tabel 7: Evaluasi Model Krisis Keuangan 1971 - 1995 (dalam sampel)

\begin{tabular}{|l|c|c|}
\hline \multicolumn{3}{|c|}{ Dalam Sampel } \\
\hline Batas Probabilitas 70\% & Logit & Probit \\
\hline NSR & 0.0251 & 0.0276 \\
\hline $\begin{array}{l}\text { Jumlah bulan pra krisis yang diprediksi dengan } \\
\text { tepat }\end{array}$ & 55,0000 & 50.000 \\
\hline $\begin{array}{l}\% \text { periode pra-krisis yang member signal } \\
\text { [AA+C] }\end{array}$ & $71,43 \%$ & $64.94 \%$ \\
\hline$\%$ signal salah [B/B+D] & $1.79 \%$ & $1.79 \%$ \\
\hline QPS & 0.1745 & 0.2081 \\
\hline GSB & 0.2222 & 0.2813 \\
\hline Ketepatan Prediksi [(A+D/(A+B+C+D)] & $91,33 \%$ & $89.67 \%$ \\
\hline Batas Probabilitas 80\% & & \\
\hline NSR & 0.0147 & 0.0177 \\
\hline $\begin{array}{l}\text { Jumlah bulan pra-krisis yang diprediksi dengan } \\
\text { tepat }\end{array}$ & 47,0000 & 39.000 \\
\hline $\begin{array}{l}\text { \% periode pra-krisis yang member signal } \\
\text { [A } \text { (C] }\end{array}$ & $61.04 \%$ & $50.65 \%$ \\
\hline$\%$ Signal Salah [B/(B+D)] & $0.90 \%$ & $0.90 \%$ \\
\hline QPS & 0.2148 & 0.2685 \\
\hline GSB & 0.2813 & 0.2813 \\
\hline Ketepatan Prediksi [(A+D/(A+B+C+D)] & $89.33 \%$ & $86.67 \%$ \\
\hline Batas Probabilitas 90\% & & \\
\hline NSR & 0.0000 & 0.0000 \\
\hline $\begin{array}{l}\text { Jumlah bulan pra-krisis yang diprediksi dengan } \\
\text { tepat }\end{array}$ & 37,0000 & $35.06 \%$ \\
\hline$\%$ periode pra-krisis yang member signal & $48.05 \%$ & 27.000 \\
\hline
\end{tabular}




\begin{tabular}{|l|c|c|}
\hline$[\mathrm{A} A+\mathrm{C}]$ & & 0 \\
\hline$\%$ Signal Salah $[\mathrm{B} /(\mathrm{B}+\mathrm{D})]$ & $0.00 \%$ & $0.00 \%$ \\
\hline QPS & 0.2685 & 0.3356 \\
\hline GSB & 0.2813 & 0.2813 \\
\hline Ketepatan Prediksi $[(\mathrm{A}+\mathrm{D} /(\mathrm{A}+\mathrm{B}+\mathrm{C}+\mathrm{D})]$ & $86.67 \%$ & $83.33 \%$ \\
\hline
\end{tabular}

Sumber: Anggito A. dan M. Handry I. (2008)

Sementara untuk mengukur probabilitas yang digunakan untuk ketepatan kalibrasi peramalan menentukan krisis keuangan. Dengan menggunakan global squared bias batas ambang tertentu maka dapat (GSB). Ketepatan peramalan probabilitas akan terjadinya krisis keuangan adalah proporsi pengamatan yang secara tepat meramalkan periode krisis dan masa tidak krisis akan dapat diukur. Indikator QPS dan GSB digunakan dengan menerapkan batas ambang diketahui seberapa akurat dari model yang dikembangkan untuk dilihat kinerjanya. Ketepatan dan nilai kalibrasi peramalan probabilitas dalam sampel mencakup periode Januari 1971 - Desember 11995 dapat dlihat pada table 7 di atas.

Tabel 8: Evaluasi Model Krisis Keuangan 1971 - 1995 (di luar sampel)

\begin{tabular}{|l|c|c|}
\hline \multicolumn{3}{|c|}{ Dalam Sampel } \\
\hline Batas Probabilitas 70\% & Logit & Probit \\
\hline NSR & 0.3693 & 0.3939 \\
\hline $\begin{array}{l}\text { Jumlah bulan pra krisis yg diprediksi dengan } \\
\text { tepat }\end{array}$ & 16.0000 & $\begin{array}{r}15.000 \\
0\end{array}$ \\
\hline$\%$ periode pra-krisis yg member signal [AA+C] & $66.67 \%$ & $62.50 \%$ \\
\hline$\%$ signal salah [B/B+D] & $24.66 \%$ & $24.66 \%$ \\
\hline QPS & 0.8624 & 0.8624 \\
\hline GSB & 0.0000 & 0.0000 \\
\hline Ketepatan Prediksi [(A+D/(A+B+C+D)] & $73.20 \%$ & $72.16 \%$ \\
\hline Batas Probabilitas 80\% & & \\
\hline NSR & 0.3939 & 0.3886 \\
\hline $\begin{array}{l}\text { Jumlah bulan pra-krisis yg diprediksi dengan } \\
\text { tepat }\end{array}$ & 15.0000 & 15.000 \\
\hline $\begin{array}{l}\text { \% periode pra-krisis yang member signal } \\
\text { [AA+C] }\end{array}$ & $62.50 \%$ & $02.50 \%$ \\
\hline$\%$ Signal Salah [B/(B+D)] & $24.66 \%$ & $24.32 \%$ \\
\hline QPS & 0.8624 & 0.8624 \\
\hline GSB & 0.0000 & 0.0000 \\
\hline Ketepatan Prediksi [(A+D/(A+B+C+D)] & $72.16 \%$ & $72.45 \%$ \\
\hline
\end{tabular}




\begin{tabular}{|l|r|r|}
\hline Batas Probabilitas $\mathbf{9 0 \%}$ & & \\
\hline NSR pra-krisis yang diprediksi dengan & 15.0000 & $\begin{array}{r}15.000 \\
0\end{array}$ \\
\hline $\begin{array}{l}\text { Jumlah bulan } \\
\text { tepat }\end{array}$ & & 62.3886 \\
\hline $\begin{array}{l}\% \text { periode pra-krisis yang member signal } \\
\text { [AA+C] }\end{array}$ & $62.50 \%$ & $62.50 \%$ \\
\hline$\%$ Signal Salah [B/(B+D)] & $24.32 \%$ & $19.74 \%$ \\
\hline QPS & 0.8440 & 0.7890 \\
\hline GSB & 0.0000 & 0.0000 \\
\hline Ketepatan Prediksi $[(\mathrm{A}+\mathrm{D} /(\mathrm{A}+\mathrm{B}+\mathrm{C}+\mathrm{D})]$ & $72.45 \%$ & $76.00 \%$ \\
\hline
\end{tabular}

Sumber: Anggito A. dan M. Handry I. (2008)

Model logit memang tidak dapat digunakan untuk meramalkan kapan tepatnya krisis keuangan akan terjadi. Tetapi model ini memberikan indikasi seberapa besar probabilitas akan terjadi krisis keuangan, bila indikator yang digunakan menunjukkan perubahan magnitude yang cukup besar dalam masa prakrisis yang dipilih. Bila keadaan cetirus paribus, maka risiko krisis tahun 2008 sudah diprediksikan dari tahun 2006, karena probabilitas krisis meningkat cukup tinggi sampai akhir tahun 2006.
4. Model Jaringan Saraf Buatan Krisis Keuangan

Dalam menggunakan : model jaringan saraf buatan dapat dipergunakan dua model, yaitu pertama: mendasarkan atas sejumlah indikator yang digunakan dałam pendekatan signal atau model KLR (Kmainsky, Lizondo dan Reinhart) dan kedua, menggunakan seluruh variabel yang digunakan model logit.

Tipologi model jaringan saraf buatan yang dipergunakan dalam penelitian ini terdiri dari 1 input layer, 1 hidden layer dan 1 out- put layer. Untuk proses iterasi, tes set ditentukan dari 50 data yang ditentukan secara acak. Proses iterasi dihentikan ketika nilai RMS error mulai meningkat.

a. Model Signal

Dapat dipergunakan 19 nodes dalam input layer, 30 nodes dalam hidden layer dan 1 nodes dalam out-put layer. Maka akan dapat dilihat besarnya kontribusi setiap indikator daam pembentukan signal. (lihat tabel 9). 
Tabel 9: Kontribusi Indikator Jaringan Saraf Buatan dengan Indikator Signal

\begin{tabular}{|c|l|c|}
\hline NO. & \multicolumn{1}{|c|}{ INDIKATOR } & $\begin{array}{c}\text { KONTRIBUSI } \\
(\%)\end{array}$ \\
\hline 1 & Nilai Tukar Rii/ Rp/US\$ (deviasi terhadap tren) & 26,78 \\
\hline 2 & Rasio Konsumsi Pemerintah dan PDB & 14,24 \\
\hline 3 & Ekspor (Perubahan Tahunan) & 12,95 \\
\hline 4 & Rasio Tingkat Bunga Pinjaman dan Tabungan & 9,18 \\
\hline 5 & Rasio M2 dengan Cadangan Devisa & 7,53 \\
\hline 6 & Tingkat Bunga Riil Tabungan & 7,26 \\
\hline 7 & Rasio Cadangan Devisa Dengan Impor & 3,95 \\
\hline 8 & Rasio Kredit Dengan PDB (Perubahan Tahunan) & 3,69 \\
\hline 9 & Rasio Defisit Fiskal Dengan PDB & 3,06 \\
\hline 10 & Cadangan Devisa & 2,93 \\
\hline 11 & Rasio Aliran Modal Jangka Pendek Dengan PDB & 2,14 \\
\hline 12 & Harga Minyak & 1,52 \\
\hline 13 & Rasio Utang Luar Negeri dan cadangan Devisa & 1,40 \\
\hline 14 & Spread Tingkat Bunga Riil *) & 0,94 \\
\hline 15 & PDB Riil (Perubahan Tahunan) & 0,77 \\
\hline 16 & Efek Penularan (Contagion) & 0,62 \\
\hline 17 & Simpanan di Perbankan & 0,52 \\
\hline 18 & M2 Multiplier (Perubahan Tahunan) & 0,34 \\
\hline 19 & Rasio Investasi PDB dengan PDB & 0,18 \\
\hline & & 100,00 \\
\hline
\end{tabular}

*) Spread bunga tabungan domestik dengan bunga The Fed.

Dalam tabel tersebut yang mempunyai kontribusi terbesar adalah deviasi nilai tukar riil (RER) terhadap tren jangka panjang. Indikator lain yang memiliki kontribusi tinggi dalam pembentukan signal Rasio Konsumsi Pemerintah dengan PDB, kemudian pertumbuhan ekspor.

Implikasinya indikator yang memiliki kontribusi besar harus lebih diperhatikan karena memberikan bobot yang lebih besar dalam pembangkitan signal akan terjadinya krisis keuangan di masa datang.

Apabila untuk kasus model dipergunakan meramal krisis pada periode di luar sampel, yaitu pada krisis 1997 - 1998 dan krisis mini pada akhir Agustus 2005, di mana rupiah hampir menyentuh $\mathrm{Rp}$ $11.000,00$ per US\$1, maka daya prediksinya relatif memadai. Pada krisis 1997 - 1998, probabilitas yang melampaui batas ambang baru muncul 1 tahun sebelumnya 
atau Agustus 1996. Idealnya probabilitas sudah naik di atas $30 \%$ pada bulan Agustus 1995 atau 24 bulan sebelumnya. Sementara krisis mini pada Agustus 2005, probabilitas naik terlalu awal, yaitu pada bulan April 2002 hingga Januari 2004.

b. Model menggunakan variabel logit
Tipologi model jaringan saraf buatan yang dipergunakan dengan menggunakan indikator yang șama dengan logit, yaitu 7 nodes dalam input layer, 5 nodes dalam hidden layer dn 1 nodes out-put layer. Hasil model jaringan saraf buatan dengan indikator yang sama dengan indikator pada model logit, maka hasilnya dapat dilihat pada tabel 10 di bawah ini.

Tabel 10: Kontribusi Indikator dlm Pembentukan Probabilitas dg. Indikator Logit

\begin{tabular}{|c|l|c|}
\hline NOMOR & \multicolumn{1}{|c|}{ INDIKATOR } & $\begin{array}{c}\text { KONTRIBUSI } \\
(\%)\end{array}$ \\
\hline 1 & $\begin{array}{l}\text { Nilai Tukar Rii/ Rp/US\$ (deviasi } \\
\text { terhadap tren) }\end{array}$ & 26,94 \\
\hline 2 & Rasio Konsumsi Pemerintah dan PDB & 24,43 \\
\hline 3 & Cadangan Devisa & 12,66 \\
\hline 4 & Ekspor (Perubahan Tahunan) & 10.45 \\
\hline 5 & $\begin{array}{l}\text { Rasio Kredit dengan PDB (Perubahan } \\
\text { Tahunan) }\end{array}$ & 9,96 \\
\hline 6 & PDB Riil (Perubahan Tahunan) & 8,19 \\
\hline 7 & Rasio Investasi PDB dengan PDB & 7,37 \\
\hline \multicolumn{2}{|c|}{ TOTAL } & 100,00 \\
\hline
\end{tabular}

Indikator yang memberikan kontribusi paling tinggi dalam membuat estimasi probabilitas adalah indikator nilai tukar riil (deviasi terhadap tren), kemudian indikator rasio konsumsi

\section{Kinerja Model}

Kinerja model dapat diukur dengan menghitung rata-rata pemerintah terhadap PDB (Pendapatan Domestik Bruto).

Untuk model kedua ini menggunakan analogi model logit supaya dapat dibandingkan dengan model signal.

penyimpangan kuadrat (mean squared error). Skor probabilitas kuadrat (quadratic probability score/QPS) Sementara itu, untuk 
mengukur ketepatan kalibrasi peramalan juga diukur dengan global squared bias (GSB). Ketepatan peramalan probabilitas akan terjadi krisis keuangan adalah proporsi pengamatan yang secara tepat meramalkan periode krisis dan masa tidak krisis akan dapat diukur.

Untuk melihat perbandingan kinerja model jaringan saraf buatan dengan model signal yang telah dibahas sebelumnya dapat dilihat pada tabel 11 . Model kinerja jaringan saraf buatan untuk periode sampel menunjukkan lebih akurat dibandingkan dengan model signal. Akan tetapi bila dilihat kinerjanya di luar sampel, dalam meprediksi kurun waktu 19962000 , di mana terdapat dua kali krisis, maka model jaringan saraf buatan kurang memuaskan dibanding model signal.

Tabel 11: Evaluasi Model Krisis Keuangan 1971 - 1995

\begin{tabular}{|l|c|c|}
\hline \multicolumn{1}{|c|}{ Batas Probabilitas 30\% } & $\begin{array}{c}\text { Model Jaringan } \\
\text { Saraf Buatan }\end{array}$ & Model Signal \\
\hline NSR & 0.0960 & 0,9105 \\
\hline $\begin{array}{l}\text { Jumlah Bulan Pra-Krisis yg } \\
\text { Diprediksi dg Tepat }\end{array}$ & 69,0000 & 58,0000 \\
\hline $\begin{array}{l}\text { \% periode pra-krisis yg } \\
\text { memberikan signal [AA+C] }\end{array}$ & 0,9583 & 0,7533 \\
\hline $\begin{array}{l}\text { \% Signal Salah [B/B+D] } \\
\text { QPS Prediksi }\end{array}$ & 0,0921 & 0,1435 \\
\hline GSB & 0,0072 & 0,3423 \\
\hline $\begin{array}{l}\text { Ketepatan } \\
\text { [(A+D)/(A+B+C+D)] }\end{array}$ & 0,3210 & 0,0556 \\
\hline
\end{tabular}


Tabel 12; Evaluasi Model Krisis Keuangan 1971 - 1995

\begin{tabular}{|l|c|c|}
\hline \multicolumn{1}{|c|}{ Batas Probabilitas 30\% } & $\begin{array}{c}\text { Model Jaringan } \\
\text { Saraf Buatan }\end{array}$ & Model Signal \\
\hline NSR & 0,7905 & 0,0999 \\
\hline $\begin{array}{l}\text { Jumlah Bulan Pra-Krisis yg } \\
\text { Diprediksi dg Tepat }\end{array}$ & 16,0000 & 20,0000 \\
\hline $\begin{array}{l}\% \text { periode pra-krisis yg } \\
\text { memberikan signal [AA+C] }\end{array}$ & 0,6667 & 0,8333 \\
\hline$\%$ Signal Salah [B/B+D] & 0,5278 & 0,0833 \\
\hline QPS Prediksi & 0,0090 & 0,6239 \\
\hline GSB & 0,3210 & 0,0000 \\
\hline $\begin{array}{l}\text { Ketepatan } \\
\text { [(A+D)/(A+B+C+D)] }\end{array}$ & 0,8833 \\
\hline
\end{tabular}

Pada tabel 13 menunjukkan ketepatan dan nilai' kalibrasi peramalan signal (periode Januari 1971 - Desember 1995). Semua ukuran. mengindikasikan tingginya daya prediksi dengan batas ambang probablitas 0,7. Pendekatan jaringan saraf buatan secara umum memberikan prediksi yang cukup baik. Model ini juga cukup baik dalam meramalkan krisis - keuangan 1997 di Indonesia, dengan memberikan peringatan dalam kurun waktu pra-krisis.

Tabel 13 : Evaluasi Model Krisis Keuangan 1971 - 1995

\begin{tabular}{|l|c|r|r|}
\hline \multicolumn{1}{|c|}{ Batas Probabilitas 70\% } & $\begin{array}{c}\text { Model Jari } \\
\text { Ngan saraf } \\
\text { Buatan }\end{array}$ & $\begin{array}{r}\text { Model } \\
\text { Logit }\end{array}$ & $\begin{array}{r}\text { Model } \\
\text { Probit }\end{array}$ \\
\hline NSR & 0,0113 & 0,0251 & 0,0314 \\
\hline $\begin{array}{l}\text { Jumlan: Bulan Pra-Krisis yg } \\
\text { Diprediksi dengan Tepat }\end{array}$ & 56,0000 & 55,0000 & $\begin{array}{r}55,000 \\
0\end{array}$ \\
\hline $\begin{array}{l}\text { \% periode pra-krisis yg } \\
\text { memberikan signal [AA+C] }\end{array}$ & 0,7778 & $0,7.143$ & 0,7143 \\
\hline $\begin{array}{l}\% \text { Signal Salah [B/B+D] } \\
\text { QPS Prediksi }\end{array}$ & 0,0088 & 0,0179 & 0,0224 \\
\hline GSB & 0,0044 & 0,1745 & 0,1812 \\
\hline $\begin{array}{l}\text { Ketepatan } \\
\text { [(A+D)/(A+B+C+D)] }\end{array}$ & 0,9400 & 0,2222 & 0,2813 \\
\hline
\end{tabular}


Tabel 14 : Evaluasi Model Krisis Keuangan 1996 - 2000

\begin{tabular}{|l|c|r|r|}
\hline \multicolumn{1}{|c|}{ Batas Probabilitas 70\% } & $\begin{array}{c}\text { Model Jari } \\
\text { Ngan saraf } \\
\text { Buatan }\end{array}$ & $\begin{array}{r}\text { Model } \\
\text { Logit }\end{array}$ & $\begin{array}{r}\text { Model } \\
\text { Probit }\end{array}$ \\
\hline NSR & 1,0321 & 0,7489 & 0,7987 \\
\hline $\begin{array}{l}\text { Jumlah Bulan Pra-Krisis yg } \\
\text { Diprediksi dengan Tepat }\end{array}$ & 20,0000 & 16,0000 & $\begin{array}{r}15,000 \\
0\end{array}$ \\
\hline $\begin{array}{l}\text { \% periode pra-krisis yg } \\
\text { memberikan signal [A/C] }\end{array}$ & 0,8333 & 0,6667 & 0,6250 \\
\hline$\%$ Signal Salah [B/B+D] & 0,8611 & 0,5000 & 0,5000 \\
\hline QPS Prediksi & 0,6435 & 0,0000 & 0,0000 \\
\hline GSB & 0,9500 & 0,9133 & 0,9100 \\
\hline $\begin{array}{l}\text { Ketepatan } \\
\text { [(A+D)/(A+B+C+D)] }\end{array}$ & & & \\
\hline
\end{tabular}

Model jaringan saraf buatan yang menggunakan indicator model logit, hasil ramalan dalam sampel menunjukkan kinerja yang lebih baik. Untuk kinerja peramalan di luar sampel, model jaringan saraf buatan menunjukkan kinerja

V. KESIMPULAN

Pengembangan ke tiga model hampir semua memberikan kinerja yang memadai dari sisi akurasi untuk meramalkan probabilitas krisis keuangan di Indonesia. Pertanyaannya adalah: model mana yang lebih baik? Tentu tidak ada jawaban yang pasti dan menyakinkan. Karena sangat tergantung pada kebutuhan penggunaan model tersebut.

Bagi Indonesia yang
perekonomiannya sering yang lebih baik disbanding model logit dan probit.

Pemakaian indicator logit dalam jaringan saraf buatan , hasilnya secara umum lebih baik untuk dalam sampel maupun di luar sampel.

Secara umum ketiga model yang dikembangkan memberikan hasil yang mirip yaitu indikator-indiktor dini yang memberikan kontribusi penting dalam meramalkan probabilitas krisis keuangan adalah kurs riil, defisit fiskal, rasio kredit terhadap PDB, harga minyak dunia, spread tingkat bunga domestik terhadap The Fed. Indikator ini dapat dijadikan indikator dini bila keadaannya tidak normal.

mengalami schock dari sektor eksternal yang sering sulit 
dihindari, maka penanganan kebijakannya adalah dengan mempekuat daya tahan perekonomian nasional. Akan tetapi bila penyebabnya berasal dari peқrekonomian domestik, maka pilihan kebijakannya menjadi lebih mudah. Faktor eksternal berupa rasio ekspor dan impor, besarnya utang luar negeri, tingginya portofolio asing di pasar modal dan pasar uang melalui pasar saham, pasar obligasi dan SBI. Sementara faktor domestiknya seperti beratnya APBN, utang dalam dan luar negeri sehingga setiap tahun harus menerbitkan surat utang baru.

Indonesia pernah mengalami krisis keuang paling parah pada tahun 1997. Pemerintah sampai sat ini belum memiliki sistem deteksi dini yang memadai kecuali yang dimiliki Bank Indonesia. Institusi yang menjadi penjaga gawang timbulnya krișis belum tertata dengan baik, dan belum memiliki sistem dan mekanisme penanganan resolusi krisis yang tidak menimbulkan implikasi hukum.

Perkembangan ekonomi semakin kompleks dan perubahan struktur ekonomi serta kelembagaan Indonesia. Oleh sebab itu pengembangan model sistem peringatan dini krisis keuangan harus terus disempurnakan sesuai dengan perkembangan ekonomi yang semakin kompleks.

\section{DAFTAR PUSTAKA}

Anggito Abimanyu dan M. Handry Imansyah. 2008. Signal untuk Sistem Peringatan Dini Krisis Keuangan di Indonesia, Sistem Deteksi Dini Krisis Keuangan di Indonesia: Penerapan Bebagai Model, BPFE UGM.

Akerlof, George A and Romer, Paul M. 1993. Looting The Economic Underworld of Bankruptcy for Profit, Bookings Paper on Economic Activity. Economic Studies Program. The Brookings Institution. Vol 24 (1993-:1 - 74)

Bank Indonesia.2003. Desaign of Early Warning System for Assessing Financial System Stability in Indonesia. Paper Presented at the Seminar of Leading Indicators on December $11 \quad 2003$. Surveillance Unit. Biro Kerja sama Luar Negeri. Depkeu. 
Frankel J.A. and A.K. Rose. 1996. Currency Crashes in Emerging Markets: An Empirical Treatment. Joumal of International Economics 41.351-366.

Muhammad Handry Imansyah. 2004. Sistem deteksi Dini Krisis Keuangan: Pendekatan Logit Untuk Indonesia. Paper disajikẳn Pada Perkuliahan Perdana Program Pasca Sarjana Universitas Lambung Mangkurat. 28 Agustus 2004. Banjarmasim.

2003. Pengembangan Sistem Peringatan Dini Krisis keuangan untuk Indonesia: Hasil Sementara. Paper Disajikan pada Seminar di Biro Kerja Sama Luar Negeri, Departemen Keuangan.12 Desember 2003. Jakarta.

Kaminsky, G.L., S. Lizondo, and C.M. Reinhart.1998. Leading Indicators of Currency Crisis. IMF Staff Papers 45-1, International Monetary Fund, Washington DC.
Krugman Paul.1979. A Model of Balance of Payment Crises. Journal of Money, Credit and Banking. Vol IIAugust. Pp.311-25.

Radelet S. and J. Sachs. 1998. The East Asian Financial Crisis: Diagnosis, Remidies, Prospect. Brookings Papers on Economic Activity 1, pp.1-7.

Saqib O.F. 2002. Interpreting Curreny Crises-A Review of Theory, Evidence and Issues. DIW Berlin-Jerman Institute for Economic Research. Discussion Paper, No. 303.

Teguh Sihono. 2009. Krisis Finansial Amerika Serikat dan Perekonomian Indonesia.Journal

Ekonomica, vol IV No 22009. FISE - UNY.

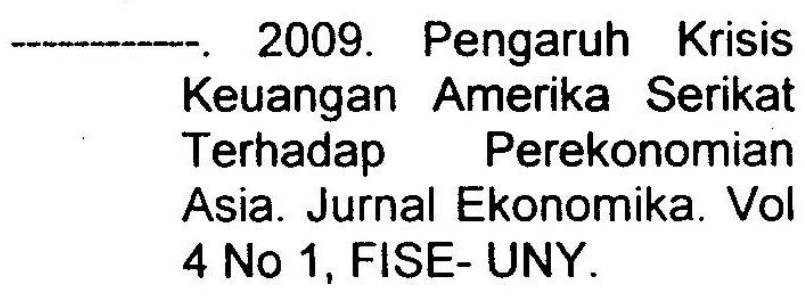


Zhuang, Juzhong. 2005. Non Parametric EWS Models of Currency and Banking Crises for East Asia, in ADB, Early Warning System for Financial Crises: Aplication to East Asia, Palgrave. Macmillan

\section{Biodata}

Teguh Sihono, MM. adalah salah satu staf pengajar pada Jurusan Pendidikan Ekonomi, Fakultas IImu Sosial dan Ekonomi, Universitas Negeri Yogyakarta 